\title{
Cryptogenic fibrosing alveolitis: clinical features and their influence on survival
}

\author{
M TURNER-WARWICK, B BURROWS, AND A JOHNSON
}

From the Cardiothoracic Institute, Brompton Hospital, London

ABSTRACT A retrospective analysis of 220 cases fulfilling criteria for cryptogenic fibrosing alveolitis (CFA) attending the Brompton Hospital between 1955 and 1973 has been carried out and patients have been followed for between four and 21 years. The frequency of various clinical features confirms previous reports. The $2: 1$ male preponderance was similar in all age groups. The mean age at presentation was 54 years \pm 12 SD; $202(92 \%)$ of the patients presented with dyspnoea, the severity of which was related to the reduction in vital capacity $(p<0.003)$ and to the radiographic profusion score $(\mathrm{p}<0.01)$ but not to its duration. Twenty-one per cent of the 220 had joint symptoms, $10 \%$ having clinical rheumatoid arthritis. Eleven per cent had other types of connective tissue disorder. In all, 30\% had polyarthritis or other immunological disorders and $70 \%$ lone CFA. Apart from an increase in rheumatoid factor in those with polyarthritis, there were no other clinical or survival differences between those with and without associated immunological disease. Forty-five per cent of 205 subjects had antinuclear antibody, and this occurred equally in those with and without associated connective tissue disorders. One hundred and forty-seven initial radiographs were available for reclassification using the ILO/UC system and only three were normal. Small rounded opacities were seen in $16 \%$ and small irregular opacities in $84 \%$. Pleural changes were uncommon. Histological confirmation had been obtained in 118 patients and material was still available for review using a semiquantitative analysis in 68 (biopsy 42 and necropsy 26). Of the biopsies one could be classified as desquamative interstitial pneumonia (DIP) and 17 as endstage fibrosis; the other 24 showed a mixed cellular and fibrotic pattern. The necropsy material showed much greater fibrosis and less acute inflammatory cellularity in spite of an interval between onset of symptoms and death of less than four years in 21 of 26 patients. One hundred and fifty-six patients have died (mean survival 3.2 years). Eleven $(5 \%$ ) are believed to be alive but have been lost to follow-up. Fifty-five per cent of deaths were attributable directly or indirectly to CFA. There was also an excess of deaths from cardiovascular disease and lung cancer. Using a life-table analysis and a $\log$ rank test, longer survival was seen in younger patients $(\mathrm{p}<0.001)$ and women $(\mathrm{p}<0.01)$. After correction for age and sex, lesser grades of dyspnoea $(p<0.03)$ and lesser radiographic abnormality $(\mathrm{p}<0.001)$, absence of right axis deviation $(\mathrm{p}<0.001)$, and a higher $\mathrm{PaO}_{2}(\mathrm{p}<0.01)$ also related to longer survival. Subjects with more cellular histology also survived longer $(p<0.02)$. Factors having no influence on survival included duration of dyspnoea before presentation, degree of reduction of FEV,$F V C$, and TLC, the presence of "connective tissue" disorders, autoantibodies, smoking history, cough, sputum, crackles, clubbing, ESR, or immunoglobulins.

Cryptogenic fibrosing alveolitis (CFA) or diffuse idiopathic pulmonary fibrosis has been the subject of several fairly large studies. ${ }^{1-4}$ While there is reasonably good agreement about the clinical defining criteria there is controversy about the

Address for reprint requests: Professor $M$ Turner-Warwick, Cardiothoracic Institute, Brompton Hospital, Fulham Road, London SW3 6HP. classification of the histological features and for this reason comparison between series is difficult. There is also controversy as to whether the clinical features and natural history of CFA associated with various forms of connective tissue disorder differs from "lone CFA". Large enough series have not been reviewed for systematic comparisons to be made. 
The overall mean survival rates reported have been similar. Carrington et $a l^{4}$ quoted 5.6 years for patients with usual interstitial pneumonia (UIP), Stack et $a l^{2}$ reponted four years, and Murao et $a l^{5}$ about three years. No series has been large enough or followed for long enough to study in depth the clinical features influencing survival. The influence of the many clinical variables on prognosis should be considered when investigating treatment.

We have studied retrospectively 220 patients fulfilling criteria for CFA who attended the Brompton Hospital over an 18-year period and were followed for between four and 21 years.

\section{Methods}

DEFINITION OF CRYPTOGENIC FIBROSING ALVEOLITIS (CFA)

The defining criteria are those described by Turner-Warwick and Haslam ${ }^{6}$ as follows:

1 All patients in whom an external fibrogenic agent could be implicated were excluded, and to this end a detailed occupational and clinical history was obtained; all patients in whom precipitins to $M$ faeni or avian antigens were found have also been excluded.

2 Where a lung biopsy was available, criteria for inclusion included the histological features of fibrosis of the alveolar walls with varying amounts of interstitial and intra-alveolar infiltrate and the absence of granuloma or intraalveolar organisation, or evidence suggesting a pneumoconiosis.

3 When no biopsy was available, the additional obligatory criteria were widespread persistent bilateral radiographic shadowing and widespread persisting crackles. Supportive but not obligatory criteria were finger clubbing and a restrictive physiological defect.

\section{STUDY POPULATION}

We identified 220 patients fulfilling the diagnostic criteria for CFA who had attended the Brompton Hospital between 1955 and 1973 under the care of one of the 13 thoracic physicians. A detailed clinical protocol was completed from the records of each patient regarding the age of onset of dyspnoea, its severity graded on a four-point scale as nil, minimal (hurrying on hills or after two flights of stairs), moderate (hurrying on the flat or after one flight of stairs), or severe (breathless at rest or on minimal exertion), and the presence and duration of cough and sputum. The smoking history was recorded. In addition, details of associated disorders in other systems were recorded, especially "connective tissue" dis $-\frac{\text { की }}{\frac{\rho}{0}}$ orders. Standard tests of lung function including measurements of ventilation and lung volumes $\frac{\bar{c}}{\bar{c}}$ were made and expressed as a percentage of the $\overparen{\widetilde{\alpha}}$ predicted value calculated from height, sex, and 0 age. ${ }^{7}$ The method used for measuring the transfer ${ }^{\infty}$ factor for carbon monoxide $\left(\mathrm{D}_{\mathrm{L}} \mathrm{CO}\right)$ was not $\vec{O}$ constant through the study and this test is not included.

The radiographs were read using the $\mathrm{ILO} /$ UC classification system ${ }^{8}$ by one of us (MTW) whose readings using this system have been com- $-\mathrm{N}$ pared with 12 others over seven years while $\omega$ serving on the Pneumoconiosis Radiology Panel. $\vec{V}$ Although the system was devised for epidemio- $\vec{\circ}$ logical use in pneumoconiosis, it has been used in 5 non-occupational lung diseases in which the $\vec{z}$ radiographic features have many similarities.

FOLLOW-UP

Records of at least four years' follow-up were $\varnothing$ available on $209(95 \%)$ of the 220 patients. All deaths have been checked through the Births and Deaths Register and causes of death checked from death certificates. One hundred and fifty-six $(75 \%)$ of the total 209 patients have been fol- 0 lowed to death. The maximum follow-up period $\propto$ for a living patient was 255 months $(21 \cdot 3$ years). $\overrightarrow{\vec{O}}$ Eleven patients could not be traced but are be- $\exists$ lieved to be alive because death certificates have not been recorded on the Births and Deaths? Register.

\section{HISTOLOGY}

The diagnosis was confirmed by lung biopsy in 66 of the $220(30 \%)$ patients and postmortem. data were available in $59(27 \%)$. Histological confirmation of the diagnosis was obtained over- $₹$ all in $118(54 \%)$ of the patients. Seven patients $\frac{\text { o }}{5}$ had both a lung biopsy and necropsy study. In $>$ all, 42 biopsies and material from 26 necropsies were available for review. This material was N classified according to a standard protocol, using a four-point grading system (grade 1 nil, grade 2 O slight, grade 3 moderate, grade 4 severe) for each $N$ type of inflammatory cell within the alveoli and within the "interstitium" of the alveolar wall.o The degree of wall fibrosis and the degree of $\frac{\mathbb{D}}{\mathscr{D}}$ destruction of the lung architecture was also $\stackrel{\oplus}{+}$ graded on a similar scale. Note was made as to $\square$ whether the changes were patchy or diffuse. The $\stackrel{\vec{P}}{\mathbb{P}}$ specimens were also graded as overall cellular (desquamative interstitial pneumonia, DIP, or $\stackrel{\mathbb{Q}}{\mathbb{Q}}$ cellular mural), fibrotic, or mixed. Fifty of the 66 biopsies had been obtained by an open procedure and, because of this, it was possible to 
undertake this semiquantitative analysis without knowledge as to whether the specimen was obtained from biopsy or necropsy material.

\section{IMMUNOLOGY}

Immunological investigations included measurement of antinuclear antibody using a double layer immunofluorescent technique, ${ }^{6}$ and measurements of rheumatoid factor, latex agglutination, and differential agglutination using the standard test with sensitised sheep red cells.

\section{ANALYSIS}

All the information was stored on the London University computer and analysed using the SPSS programme. Comparison of data has usually been made using chi-square analysis, with the Yates correction where appropriate unless otherwise stated. The survival data have been analysed using a log rank routine, devised by Peto et al. ${ }^{9}$ This technique allows comparison of the survival in different groups, with the ability to control the effect of one or more other variables while examining the independent effect of the variable under study. Findings for each group are reported as observed deaths compared to the number of deaths expected in the group based on the survival data from the total sample. Comparison of observed and expected deaths for each sex and in each age group enables an age and sex adjustment to be made when the influence upon survival of other variables is being studied.

Survival data were also analysed comparing survival in three groups-deaths within two years of onset, deaths between two and four years, and alive at four years. In almost every instance the grouped data showed the same trends and significance as the log rank method, and the results using both methods have been combined.

\section{Results}

\section{AGE, SEX, AND OCCUPATION}

There were 147 men $(66 \cdot 8 \%)$ and $73(32 \cdot 2 \%)$ women. The occupations were recorded in 205 instances and showed a distribution similar to that of the general population.

The mean age from the onset of dyspnoea was 54.9 years $\pm 12.0 \mathrm{SD}$ (median 56 years and the range 18-84 years). The mean age at presentation at the Brompton Hospital was $57 \cdot 6 \pm 11 \cdot 3$ SD (median 58.7 years and range 19-84 years). The sex distribution was similar in all age groups. Younger patients had more dyspnoea $(p<0.001)$, a lower \% predicted FEV 1 (p<0.04) and \% predicted FVC $(p<0.01)$ but less severe radio- graphic changes $(\mathrm{p}<0.02)$ and a lower erythrocyte sedimentation rate.

\section{SYMPTOMS}

Dyspnoea Two hundred and two (92\%) patients presented with dyspnoea; its duration varied from less than four weeks to 21 years (fig 1). Ninetysix (44\%) patients had dyspnoea for less than one year and the mean duration for the whole series was $2 \cdot 1$ year $\pm 2.8 \mathrm{SD}$. Of 161 patients where quantitative data were available, $51 \%$ had grade $1,28 \%$ had grade $2,13.7 \%$ had grade 3 , and $7.5 \%$ had grade 4 . The severity of dyspnoea was unrelated to the duration of the symptoms. Of 65 cases with symptoms for less than one year, $52 \%$ had grade 1 and $6 \%$ had grade 4 . Of the 40 patients having dyspnoea for more than four years from presentation, $43 \%$ were still grade 1 and $7 \cdot 5 \%$ grade 4 . Seventy-eight per cent of 161 patients had relatively mild symptoms (grade 1 or 2) at the time of presentation. There was no difference in the degree of dyspnoea between the sexes, in relation to smoking history, the presence of immunological disease, or histological appearances. Neither was there a significant difference in the severity of dyspnoea with the age of presentation. There was, however, a significant relationship between the degree of dyspnoea and the radiographic profusion score $(p<0.01)$ and the extent of reduction in \% predicted vital capacity $(p<0.003)$. The duration of dyspnoea however did not relate either to the radiographic or physiological changes.

Cough and sputum Seventy-three per cent of the 220 patients had cough and $56.8 \%$ produced sputum. The mean declared duration of cough was only 4.8 years $\pm 6.4 \mathrm{SD}$, and $68 \%$ of those with cough claimed that the duration was for less than five years. Similarly $63 \%$ of those with sputum stated that it had been present for less than five years. Seventy-four per cent of 210 were smokers or ex-smokers.

Clinical signs Ninety-six per cent of 220 patients had widespread crackles and $66 \%$ had finger clubbing. Twenty-one per cent had joint signs and/or symptoms, and clinical rheumatoid arthritis was found in $10 \%$ of the whole group. Other types of connective tissue disorder were found in $10.9 \%$. These included chronic active hepatitis (six), Sjögren's syndrome (one), polymyositis (two), scleroderma (one), ulcerative colitis (four), thyroid disease (six), pernicious anaemia (two), digital vasculitis (two). Overall, $30 \%$ of the patients had associated polyarthritis and other immunological disorders, the rest having "lone" CFA. 
OTHER ASSOCIATED DISEASES

AT PRESENTATION

Other associated diseases occurred with frequencies similar to a random population of similar age and sex and included hypertension (two), diabetes (three), ischaemic heart disease (five), peptic ulcer (two), pulmonary tuberculosis (three), valvular heart disease (one). Four cases had lung cancer at presentation. Eleven of 206 $(5 \%)$ cases had right ventricular failure.

\section{PHYSIOLOGY}

The mean per cent predicted $\mathrm{FEV}_{1}$ was $65 \cdot 1 \pm$ 19.7 SD, the mean per cent predicted FVC $64 \cdot 1$ $\pm 18.9 \mathrm{SD}$, and the mean per cent predicted TLC $74 \cdot 7 \pm 20 \cdot 8$ SD. The per cent predicted FVC showed a significant relationship with age, younger patients having more severe impairment $(p<0.01)$. There was no relationship between the severity of physiological abnormality and sex or smoking history.

There was a strong correlation between the degree of dyspnoea and the reduction of $\mathrm{FEV}_{1}$ and FVC $(\mathrm{p}<0.001$ and $<0.003$ respectively). There was no relationship, however, between the $\mathrm{FEV}_{1} / \mathrm{FVC}$ ratio and dyspnoea; only $17 \%$ of 168 cases in whom appropriate data were available had a ratio of less than $90 \%$. There was no relation between TLC and the duration of breathlessness. Physiological measurements did not show a relationship with the histological classification in the 38 cases analysed, neither was there a correlation between total lung capacity and radiographic profusion score or number of zones involved. However, where the $\mathrm{FEV}_{1} / \mathrm{FVC}$ ratio

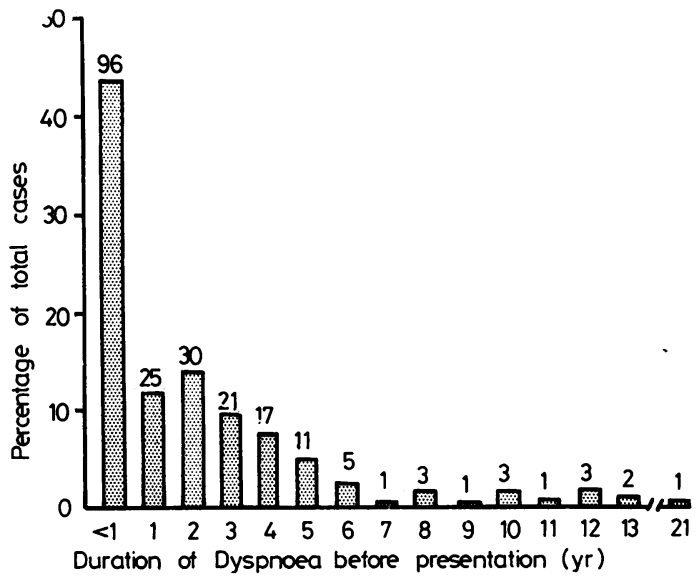

Fig 1 Duration of dyspnoea in years before presentation to hospital (220 patients). was greater than $90 \%$, more zones were affected $\stackrel{\overrightarrow{\bar{F}}}{\stackrel{5}{\circ}}$ $(\mathrm{p}<0.02)$.

CHEST RADIOGRAPHY

This was normal in three of $147(2.0 \%)$ patients where a satisfactory initial film was available. ळ Small irregular opacities were seen in $77 \%$ of $\overrightarrow{0}$ 147 initial films and small round opacities were seen in $16 \%$. A diffuse haze not apparently $\vec{\omega}$ caused by pleural shadows and representing a? category not included in the ILO/UC system was $x$ seen in $6.7 \%$. The film quality was unsatisfactory for a profusion score to be made in seven in- $\omega$ stances. The distribution of the profusion scores is seen in fig 2 , the median score being $2 / 1$. The frequency of involvement of each radiographic오 zone is shown in table 1 . Rounded lesions seem ${ }_{-}^{-}$ to have been uniformly distributed while smallo irregular opacities were more than twice as commonly found in the lower zones. About a third. of the cases had all six zones involved at the time of presentation (fig 3). Large opacities were recorded in only seven of 151 initial films. Costo-O phrenic angle obliteration was seen in only 15 of 146 films and pleural thickening in only six. Lack of definition of the diaphragm and cardiac out line were recorded in 19 out of 50 and 23 out of 150 respectively. Pleural calcification was never $\overrightarrow{\vec{P}}$ seen. Gross honeycombing was recorded in only⿳ eight instances, but minor grades of honeycomb-? ing were common.

The profusion score correlated with the degree of dyspnoea at presentation $(p<0.01)$ and alb cases with grade 4 dyspnoea had a profusioner score of $2 / 1$ and over. However, there were 360 cases with a greater than $2 / 1$ radiograph having. grade 1 dyspnoea or less. There was also a significant correlation between the degree of dyspnoea and number of zones involved $(p<0.04)$.

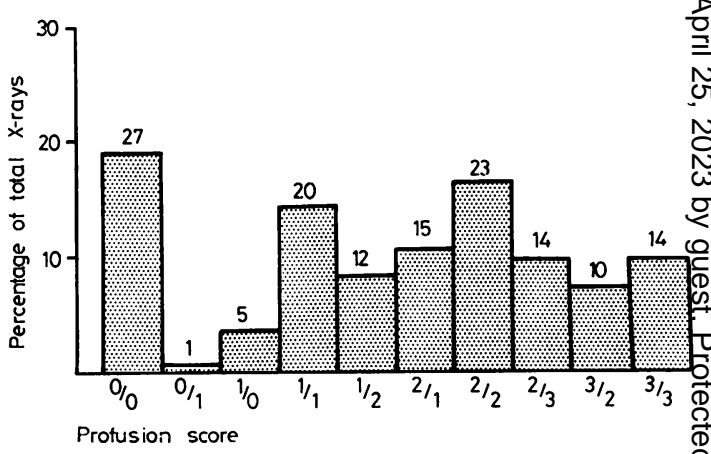

Fig 2 Distribution of the profusion of small irregular opacities using the ILO/UC classification (141 patients). 
Table 1 Distribution of rounded and irregular opacities in the radiographs of 147 patients with $C F A$

\begin{tabular}{llllllllll} 
& \multicolumn{3}{c}{$\begin{array}{l}\text { Rounded } \\
(\mathrm{n}=24)\end{array}$} & \multicolumn{5}{c}{$\begin{array}{c}\text { Irregular } \\
(\mathrm{n}=123)\end{array}$} \\
\cline { 2 - 10 } & $R$ & $\%^{*}$ & $L$ & $\%^{*}$ & $R$ & $\%^{*}$ & $L$ & $\%^{*}$ \\
\hline Upper & 15 & 10 & 13 & 9 & 65 & 43 & 49 & 33 \\
Mid & 17 & 12 & 19 & 13 & 87 & 58 & 85 & 55 \\
Lower & 20 & 14 & 20 & 14 & 113 & 75 & 121 & 81
\end{tabular}

*Percentages refer to the frequency of rounded or irregular shadows in the whole series of 147 patients.

\section{ELECTROCARDIOGRAPHY}

A left axis shift on the first ECG available further than $-20^{\circ}$ was seen in 20 of 161 cases. A right axis shift further than $+90^{\circ}$ was found in 18 instances.

\section{IMMUNOLOGY}

The erythrocyte sedimentation rates are set out in table $2,37 \%$ of 208 subjects having an initial level greater than $40 \mathrm{~mm}$ in one hour. Total immunoglobulins over $36 \mathrm{~g} / 1$ occurred in about a third of the cases. Antinuclear antibody (ANA) was present in titres of 1 in 10 and over in $45 \%$ of 205 cases. About a quarter of cases had an ANA titre of 1 in 20 or greater; the immunofluorescent pattern was most frequently diffuse.

A differential agglutination titre (DAT) of 1 in 32 or over was found in $17 \%$ of 197 cases and a positive latex slide test in $33.5 \%$ of 200 , a strongly positive reaction being seen in $5.5 \%$ of 200. The relationship between antinuclear antibody and rheumatoid factor and associated immunological disease is shown in table 3 .

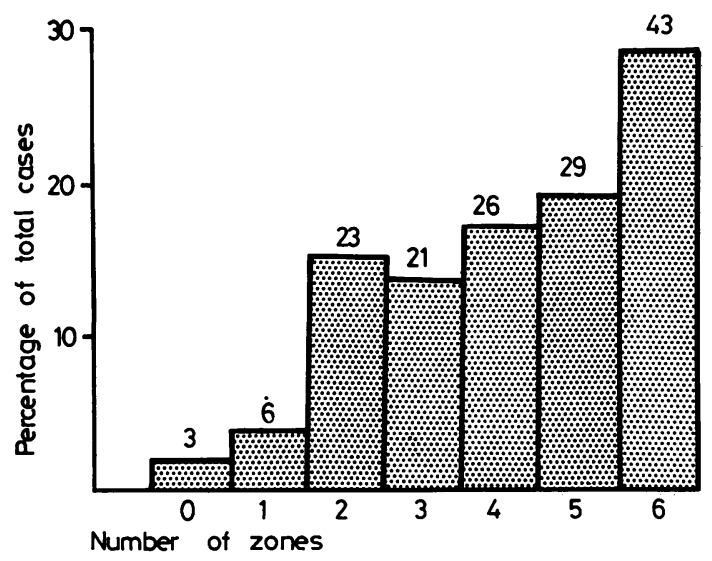

Fig 3 Distribution of number of zones affected on the initial chest radiograph (151 patients).
Table 2 Erythrocyte sedimentation rate (ESR), total globulins, and antinuclear antibody titres in CFA

$\left.\begin{array}{lccc}\hline & & \text { Number } & \% \text { of total } \\ \hline \text { ESR mm/hr } & 20 & 77 & 37 \cdot 0 \\ (\mathrm{n}=208) & 20-39 & 54 & 26 \cdot 0 \\ & 40-59 & 42 & 20 \cdot 2 \\ & 60-79 & 21 & 10 \cdot 1 \\ & <80 & 14 & 6 \cdot 7\end{array}\right\} 37 \cdot 0 \%$

Apart from the association between rheumatoid factors and polyarthritis, there was no association between the frequency and titre of ANA or rheumatoid factor in any of the clinical features studied. In particular, ANA did not relate to the severity of the radiographic changes.

\section{HISTOLOGY}

Histological verification of the diagnosis has been obtained in 118 instances; by lung biopsy in 66 and necropsy in 59. Open lung biopsy was performed in 50 patients, a de Soutter/Steel trephine drill biopsy in eight and other needle biopsies in eight. Overall there were one death, five pneumothoraces, five wound infections, and four patients suffered acute distress with breathlessness as a result of biopsy. Semiquantitative analysis was carried out on the 42 biopsies and 26 necropsy specimens available (table 4).

Only occasional inflammatory cells were seen in the alveolar spaces, including neutrophils, eosinophils, and lymphocytes. Large mononuclear cells were always observed but were numerous in only eight (19\%). One of these cases showed uniform filling of alveoli with relatively slight alveolar wall fibrosis, fulfilling the criteria of DIP. Seventeen biopsies showed endstage fibrosis with or without honeycombing. The remainder showed a variable interstitial and intraalveolar inflammatory cell infiltrate with varying degrees of fibrosis, fulfilling the criteria for UIP. The main interstitial cell was the lymphocyte and these were moderately frequent in about a third of cases. Plasma cells in moderate numbers were seen in $11 \%$ of the cases. Germinal follicles were seen in about half the biopsy specimens. Overall $39 \%$ were regarded as mainly cellular and $41 \%$ - as fibrotic; $20 \%$ were graded as mixed. 
Table 3 Autoantibodies and the presence of immunological disease in cryptogenic fibrosing alveolitis

\begin{tabular}{|c|c|c|c|c|c|c|c|}
\hline & \multirow{2}{*}{$\begin{array}{l}\text { Total } \\
\text { patient } \\
\text { data } \\
\text { recorded }\end{array}$} & \multicolumn{2}{|l|}{ ANA } & \multicolumn{2}{|l|}{$D A T$} & \multicolumn{2}{|l|}{ Either } \\
\hline & & $\begin{array}{l}\text { Number }+v e / \\
\text { number studied }\end{array}$ & $\%+v e$ & $\begin{array}{l}\text { Number +vel } \\
\text { number studied }\end{array}$ & $\%+v e$ & $\begin{array}{l}\text { Number +vel } \\
\text { number studied }\end{array}$ & \\
\hline \multirow{2}{*}{$\begin{array}{l}\text { Joints } \\
\text { signs or } \\
\text { symptoms }\end{array}$} & Present & $21 / 43$ & 49 & $16 / 43$ & 37 & $26 / 43$ & 60 \\
\hline & Absent & $26 / 54$ & $\begin{array}{l}48 \\
\text { NS }\end{array}$ & $8 / 54$ & $\begin{array}{l}15 \\
p<0.03\end{array}$ & $32 / 54$ & $\begin{array}{l}54 \\
\text { NS }\end{array}$ \\
\hline \multirow{2}{*}{$\begin{array}{l}\text { Other } \\
\text { immunological } \\
\text { disease }\end{array}$} & Present & $10 / 24$ & 42 & $5 / 22$ & 23 & $14 / 23$ & 61 \\
\hline & Absent & $82 / 181$ & $\begin{array}{l}45 \\
\text { NS }\end{array}$ & $28 / 175$ & $\begin{array}{l}16 \\
\text { NS }\end{array}$ & $93 / 177$ & $\begin{array}{l}53 \\
\text { NS }\end{array}$ \\
\hline \multirow{2}{*}{$\begin{array}{l}\text { Joints and/or } \\
\text { immunological } \\
\text { disease }\end{array}$} & Present & $31 / 64$ & 50 & $21 / 62$ & 34 & $37 / 60$ & 62 \\
\hline & Absent & $23 / 46$ & $\begin{array}{l}50 \\
\text { NS }\end{array}$ & $5 / 47$ & $\begin{array}{l}11 \\
p<0.01\end{array}$ & $25 / 45$ & $\begin{array}{l}56 \\
\text { NS }\end{array}$ \\
\hline
\end{tabular}

*For definition see Methods.

Table 4 Semiquantitative analysis of histological appearances

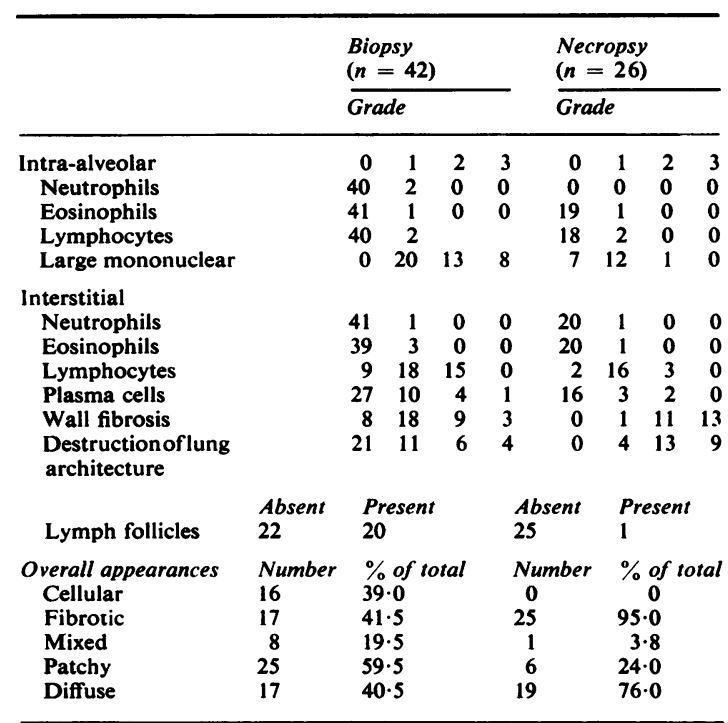

There was a consistent trend towards more fibrosis and lung destruction and less cellularity in the necropsy material, in spite of the fact that many cases died within a relatively few years of presentation (mean duration from onset of symptoms to death was 4.3 years and $81 \%$ of 26 died within four years of first symptoms). The mean duration of symptoms until lung biopsy was $1 \cdot 7$ years and in 33 of $34(97 \%)$ the interval was less than four years. No relationship was found between histological appearances and sex, age at onset, duration or degree of dyspnoea, or physiological or radiographic abnormality. Steroid responsiveness in relation to histology is discussed elsewhere. ${ }^{10}$

\section{FOLLOW-UP}

A total of 156 patients have been followed to death. The remainder are alive and have beeff followed for a minimum of four years. Overalt $50 \%$ of the population were alive at 4.5 years ando $25 \%$ at $8 \cdot 1$ years. The mean survival from presentation of those followed to death was $3 \cdot 2$ years and the mean survival of those living $8 \cdot 8$ years.

Age and sex had a marked influence on suro vival, younger patients and women surviving longer (fig 4 and 5). These factors operate ine dependently in that there was still a striking ag $\overline{\vec{E}}$ influence when standardised for sex $(p<0.001$ 尹 and females survived better in all age group $(p<0.005)$. The various clinical factors relating to survival, even when age and sex have beep taken into account, are shown in table 5. A lesser degree of dyspnoea at presentation and lesser radiographic profusion, a higher $\mathrm{PaO}_{2}$ i the absence of right heart failure and absence of right axis deviation are all related to longe? survival. The lesser radiographic profusion scores

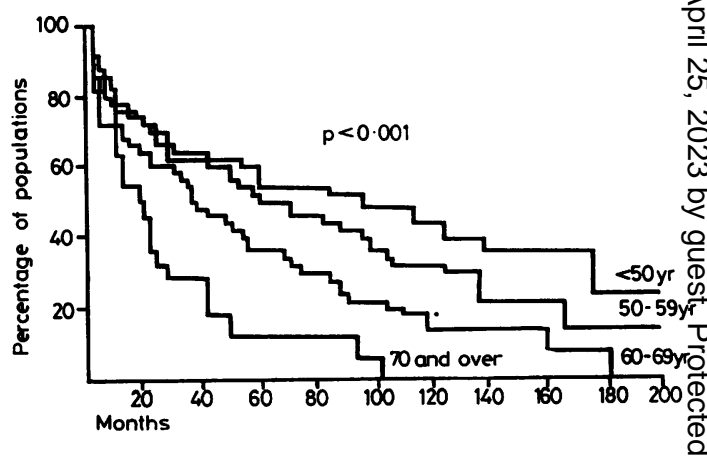

Fig 4 Survival curves for 209 patients in whom adequate follow-up information was available showing the relation to age. 


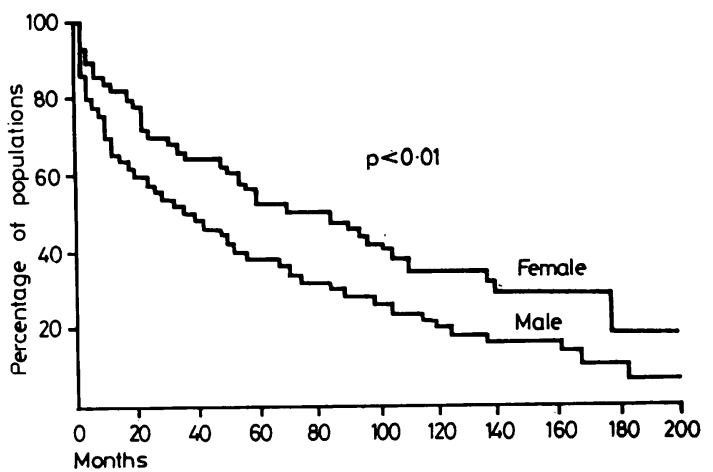

Fig 5 Survival curves for 209 patients in whom adequate information was available showing the better survival in women.

also related to better survival (fig 6).

Cellularity and less fibrosis on the lung biopsy related to longer survival (fig 7) but this difference was eliminated when corrected for age and sex.

Table 5 Clinical factors relating to survival

\begin{tabular}{|c|c|c|c|c|c|}
\hline & Factor & Number & $\begin{array}{l}\text { Median } \\
\text { survival } \\
(m o)\end{array}$ & $\begin{array}{l}\text { Uncorrected } \\
p \text { value }\end{array}$ & $\begin{array}{l}P \text { value } \\
\text { corrected } \\
\text { for age } \\
\text { and sex }\end{array}$ \\
\hline Sex & $\begin{array}{l}\text { Women } \\
\text { Men }\end{array}$ & $\begin{array}{r}68 \\
113\end{array}$ & $\begin{array}{l}77 \cdot 5 \\
40\end{array}$ & $<0.01$ & $<0.005$ \\
\hline $\begin{array}{l}\text { Age } \\
\text { (yr) }\end{array}$ & $\begin{array}{l}<30 \\
30-39 \\
40-49 \\
50-59 \\
60-69 \\
70 \text { and over }\end{array}$ & $\begin{array}{r}3 \\
13 \\
26 \\
71 \\
74 \\
22\end{array}$ & $\left.\begin{array}{r}92.5 \\
120.0 \\
77.5 \\
70.0 \\
45.0 \\
17.5\end{array}\right\}$ & $<0.001$ & 0.001 \\
\hline $\begin{array}{l}\text { Dysp } \\
\text { Gr }\end{array}$ & $\begin{array}{l}\text { loea } \\
\text { de } 0-1 \\
2-4\end{array}$ & $\begin{array}{r}34 \\
149\end{array}$ & $\begin{array}{l}94 \\
42\end{array}$ & $<0.03$ & $<0.03$ \\
\hline $\begin{array}{r}\text { Righ } \\
\text { Ab } \\
\text { Pre }\end{array}$ & $\begin{array}{l}\text { heart failure } \\
\text { ent } \\
\text { sent }\end{array}$ & $\begin{array}{r}186 \\
20\end{array}$ & $\begin{array}{r}53 \\
4\end{array}$ & $<0.001$ & $<0.001$ \\
\hline $\begin{array}{r}\text { Radi } \\
<1 \\
1 / 2 \\
2 / 1 \\
3 / 2\end{array}$ & $\begin{array}{l}\text { graphic pictur } \\
12 \\
-2 / 0 \\
-3 / 1 \\
\text { and over }\end{array}$ & $\begin{array}{l}\text { e } \\
37 \\
10 \\
60 \\
28\end{array}$ & $\begin{array}{r}136 \\
84 \\
41 \\
11\end{array}$ & $<0.003$ & $<0.001$ \\
\hline $\begin{array}{c}\mathrm{PaO}_{2} \\
< \\
45 \\
60 \\
80\end{array}$ & $\begin{array}{l}45 \\
59 \\
79 \\
\text { and over }\end{array}$ & $\begin{array}{l}15 \\
36 \\
36 \\
18\end{array}$ & $\begin{array}{r}4 \\
30 \\
70 \\
62\end{array}$ & $<0.08$ & $<0.01$ \\
\hline $\begin{array}{c}\text { ECG } \\
< \\
0-\varepsilon \\
>\end{array}$ & $\begin{array}{l}\text { axis } \\
0 \\
9 \\
90\end{array}$ & $\begin{array}{l}44 \\
90 \\
18\end{array}$ & $\begin{array}{l}48 \\
59 \\
22\end{array}$ & $<0.03$ & $<0.001$ \\
\hline $\begin{array}{r}\text { Biops } \\
\text { Ce } \\
\text { Fit } \\
\text { Mi }\end{array}$ & $\begin{array}{l}\text { y } \\
\text { ular } \\
\text { rotic } \\
\text { sed }\end{array}$ & $\begin{array}{r}16 \\
16 \\
7\end{array}$ & & $<0.02$ & $0 \cdot 1 \mathrm{NS}$ \\
\hline
\end{tabular}

Clinical factors not influencing the overall natural history were the presence of polyarthritis or other immunological disease, the presence of cough and sputum, smoking habits, the presence of immunological markers including autoantibodies, a raised sedimentation rate, or raised globulin.

\section{CAUSES OF DEATH}

Main causes are set out in table 6. One hundred and eleven of 156 patients died a respiratory death and it is likely that fibrosing alveolitis was a contributing factor in at least 96 . The evidence of the excess cancer risk in patients with CFA is demonstrated and will be discussed in detail in a later paper. ${ }^{11}$ Fibrosing alveolitis may also have been a contributing factor in 15 patients dying from chronic bronchitis (three) and other pulmonary infections (12). The relative risks of death from various causes and showing the overall excess in both sexes of all ages allowing for the duration of follow-up are summarised in table 7. Nineteen patients died from cardiovascular disease, representing a fourfold increase over a sex and age-matched general population. There also appeared to be excess deaths from pulmonary embolism, but the numbers of expected deaths from this cause are too few for conclusions to be drawn.

\section{Discussion}

Cryptogenic fibrosing alveolitis is a relatively uncommon condition. It is thus difficult to study sufficient numbers of patients on which to base general statements. The problem is made more difficult because of the heterogeneity of the con-

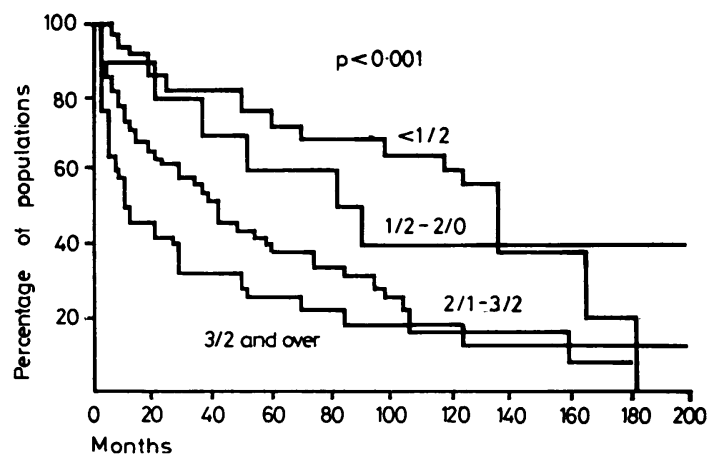

Fig 6 Survival curves for 135 patients in whom adequate information was available showing the better survival in those with less severe initial profusion scores. 


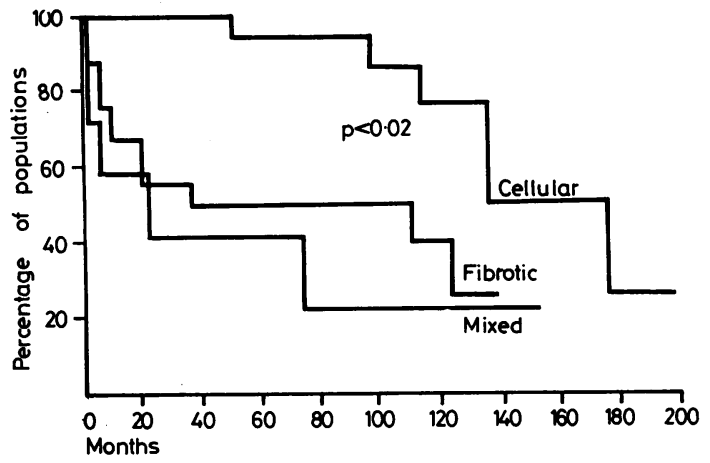

Fig 7 Survival curves in 39 patients in whom the biopsy material could be reviewed showing the better survival of those with a "cellular" type of biopsy appearance.

dition. Survival varies widely in spite of similar lengths of dyspnoea at presentation. The factors

Table 6 Causes of death $(n=156)$

\begin{tabular}{|c|c|c|}
\hline Cause & & $\begin{array}{l}\% \text { of } \\
\text { deaths }\end{array}$ \\
\hline Directly associated with CFA & 267 & \\
\hline $\begin{array}{l}\text { Heart failure } \\
\text { Infection }\end{array}$ & $\left.\begin{array}{r}39 \\
6\end{array}\right\} 71$ & $45 \cdot 5$ \\
\hline Lung cancer & 20 & $12 \cdot 8$ \\
\hline Cardiovascular disease & & \\
\hline $\begin{array}{l}\text { Ischaemic heart disease } \\
\text { Cardiovascular accidents }\end{array}$ & $\left.\begin{array}{r}12 \\
7\end{array}\right\} 19$ & $12 \cdot 2$ \\
\hline Other infections & 12\{ & \\
\hline Chronic bronchitis & $3\} 15$ & $9 \cdot 6$ \\
\hline Pulmonary embolism & 5 & $3 \cdot 2$ \\
\hline \multicolumn{3}{|l|}{ Others } \\
\hline Peptic ulcer & 3 & 1.9 \\
\hline Cirrhosis & 3 & 1.9 \\
\hline Miscellaneous & 20 & $12 \cdot 8$ \\
\hline
\end{tabular}

influencing survival have to be carefully analysed $\stackrel{\bar{F}}{\stackrel{5}{+}}$ if standardised groups of patients are comparedo for any clinical or therapeutic purpose. In particular, understanding of factors influencing survival is important before attempting to assess the 2 effects of therapy.

In order to obtain a large series and to ensure $\vec{\circ}$ an adequate follow-up, a retrospective study, with all its inherent limitations, was considered justi- $\vec{\omega}$ fied. To some extent the large numbers of cases included in each analysis compensate for incom- $\vec{x}$ plete information. A more serious criticism of $\mathrm{G}$ our series is the fact that the Brompton Hospitalic is a secondary referral centre and more severe $\overrightarrow{-}$ cases are likely to be seen at a somewhat laterstage that those attending other centres. How-으 ever, the facts that only 32 of a total of $143-$ patients treated with corticosteroids received any treatment before attendance at the Brompton, $\overline{\mathcal{C}}$ that half of our cases had grade 1 dyspnoea, and $29 \%$ had had dyspnoea for less than one year,,$\infty$ and that $46 \%$ had a $1 / 2$ profusion score or less. on the chest radiograph, suggest that our study included the whole spectrum of disease.

Only one of 66 patients whose histology wasō available showed the characteristics of diffuse⿳亠丷厂 interstitial pneumonia; the great majority showed $\mathbb{Q}$ features which would correspond to active UIP $\overrightarrow{\vec{O}}$ or to endstage fibrosis. The explanation for the 3 infrequency of DIP in our series is unknown.? In part, it may be related to case selection since a considerable number of cases included by Carrington et al $^{4}$ were apparently young individualso with normal radiographs or without dyspnoea, patients not found in our study.

Table 7 Observed and expected deaths by age and sex in cryptogenic fibrosing alveolitis

\begin{tabular}{|c|c|c|c|c|c|c|c|c|c|c|c|c|}
\hline & \multicolumn{3}{|c|}{$\begin{array}{l}\text { Ischaemic } \\
\text { heart disease }\end{array}$} & \multicolumn{3}{|c|}{$\begin{array}{l}\text { Cerebrovascular } \\
\text { disease }\end{array}$} & \multicolumn{3}{|c|}{$\begin{array}{l}\text { Lung infections, } \\
\text { pneumonia and } \\
\text { bronchitis }\end{array}$} & \multicolumn{3}{|c|}{ Totals } \\
\hline & $O$ & $E$ & $O / E$ & $O$ & $E$ & $O / E$ & $O$ & $E$ & $O / E$ & $O$ & $E$ & $O / E$ 을. \\
\hline $\begin{array}{l}\text { Male } \\
15-49 \mathrm{yr} \\
50-59 \mathrm{yr} \\
60-69 \mathrm{yr} \\
70 \mathrm{yr} \text { and over }\end{array}$ & $\begin{array}{l}1 \\
2 \\
4 \\
1\end{array}$ & $\begin{array}{l}0 \cdot 07 \\
1 \cdot 08 \\
1 \cdot 89 \\
0.60\end{array}$ & $\begin{array}{r}142.9 \\
1.9 \\
2 \cdot 1 \\
16.7\end{array}$ & $\begin{array}{l}\overline{4} \\
1 \\
-\end{array}$ & $\begin{array}{l}0.01 \\
0.18 \\
0.49 \\
0.30\end{array}$ & $\begin{array}{l}\overline{22 \cdot 2 *} \\
2 \cdot 0 \\
-\end{array}$ & $\begin{array}{l}2 \\
2 \\
5 \\
3\end{array}$ & $\begin{array}{l}0.01 \\
0.21 \\
0.60 \\
0.39\end{array}$ & $\begin{array}{r}200 \cdot 0^{*} \\
9 \cdot 5^{*} \\
8 \cdot 3^{*} \\
7 \cdot 7^{*}\end{array}$ & $\begin{array}{c}16 \\
34 \\
41 \\
11\end{array}$ & $\begin{array}{l}0 \cdot 27 \\
2 \cdot 83 \\
5 \cdot 52 \\
2 \cdot 20\end{array}$ & $\begin{array}{r}58 \cdot 4 * \\
12 \cdot 0 * \mathrm{~N} \\
7 \cdot 4 * \mathrm{~N} \\
5 \cdot 0 \mathrm{\omega}\end{array}$ \\
\hline Totals & 8 & 3.64 & $2 \cdot 2^{*}$ & 5 & 0.98 & $5 \cdot 1 *$ & 12 & $1 \cdot 21$ & $9 \cdot 9 *$ & 102 & $10 \cdot 83$ & $\frac{9 \cdot 7^{4}<}{10}$ \\
\hline $\begin{array}{l}\text { Female } \\
15-49 \mathrm{yr} \\
50-59 \mathrm{yr} \\
60-69 \mathrm{yr} \\
70 \mathrm{yr} \text { and over }\end{array}$ & $\begin{array}{l}- \\
1 \\
2 \\
1\end{array}$ & $\begin{array}{l}0.01 \\
1.6 \\
0.40 \\
0.48\end{array}$ & $\begin{array}{l}\overline{0 \cdot 6} \\
5 \cdot 0 \\
2 \cdot 1\end{array}$ & $\begin{array}{l}2 \\
- \\
-\end{array}$ & $\begin{array}{l}0.01 \\
0.09 \\
0.21 \\
0.39\end{array}$ & $\begin{array}{l}200 \cdot 0^{*} \\
- \\
-\end{array}$ & $\begin{array}{l}- \\
\overline{1} \\
2\end{array}$ & $\begin{array}{l}0.01 \\
0.06 \\
0.12 \\
0.26\end{array}$ & $\begin{array}{l}- \\
\overline{8 \cdot 3} \\
7 \cdot 7 *\end{array}$ & $\begin{array}{r}7 \\
12 \\
13 \\
10\end{array}$ & $\begin{array}{l}0.12 \\
1.04 \\
1.67 \\
1.97\end{array}$ & 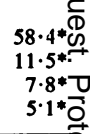 \\
\hline Totals & 4 & $1 \cdot 05$ & $3 \cdot 8^{*}$ & 2 & 0.71 & $2 \cdot 8$ & 3 & 0.45 & $6 \cdot 7^{*}$ & 42 & $4 \cdot 80$ & \\
\hline Totals & 12 & $4 \cdot 69$ & $2 \cdot 6^{*}$ & 7 & 1.69 & $4 \cdot 1^{*}$ & 15 & 1.66 & $9 \cdot 0^{*}$ & 144 & $15 \cdot 63$ & $9 \cdot 2 * \sigma$ \\
\hline
\end{tabular}


In spite of the limitations introduced by the unsatisfactory criteria which have to be used to define a clinical syndrome of unknown cause or causes, and the difficulties of retrospective case collection, the characteristics of the large population included in the present report are remarkably similar to those in other series. ${ }^{245}$ The high prevalence of antinuclear antibody we reported previously has been confirmed. Stack $e t a l^{2}$ found ANA in $30 \%$ of his subjects, but others have found a lower frequency. ${ }^{35}$ The reason for this is unknown.

There is also close agreement between reported series regarding survival patterns, the mean survival till death being 3.2 years in the present series compared with 3.0 years, 4.0 years, and 5.6 years respectively in other studies. ${ }^{52} 4$ Twentynine per cent of Carrington's cases and $28 \%$ of the present series were alive at 10 years. Analysis of survival data has been undertaken using a log rank test. ${ }^{9}$ This method compares the death rates over the complete follow-up time in each of a number of subgroups of the population compared to the expected rates for the entire series. The influence of certain clinical factors on survival has been noted in other reports. The better survival of young patients and females was noted by others. ${ }^{12}$ Our results also confirm the observation that the lesser grades of dyspnoea at presentation and higher $\mathrm{PaO}_{2}$ relate to better survival. ${ }^{2}$ In addition, we have shown that longer survival relates to lesser radiographic abnormality.

The influence of histological appearances on survival is important and comparison with results reported by other workers is especially difficult because of the different methods used for analysis. Carrington et $^{2} \mathbf{l}^{4}$ showed a striking difference in survival (and steroid response) between DIP and UIP. Several groups of workers note a better steroid response in more cellular cases of UIP, ${ }^{2451213}$ but they do not relate steroid responsiveness to survival data. In the present study, greater cellularity appeared to relate to survival $(p<0.02)$ but this was not significant when corrected for age and sex. Because of the small numbers studied it is difficult to determine whether this is simply a reflection of age and sex per se or the result of the histological feature. The question of histology and steroid responsiveness and survival is considered in more detail elsewhere. ${ }^{10}$

Comparison of the biopsy and necropsy data is of interest. Twenty-one of 26 cases came to necropsy within four years of onset of symptoms and showed no evidence of dying from uncontrolled active disease but rather from progressive non-cellular fibrosis. This observation has led to a tentative hypothesis that progression of cryptogenic fibrosing alveolitis depends upon two factors or groups of factors-first, that determining acute injury and second, those determining progressive fibrosis. Evidence has been presented by Dreisen et $a l^{12}$ that circulating immune complexes can be found in patients with more cellular histology but not in those with fibrotic acellular disease. Immune complexes may therefore be important in pathogenesis as initiating factors of lung injury. ${ }^{14}$ These findings were also in accordance with the earlier finding that immune complexes were not seen in biopsies from more fibrotic specimens. ${ }^{15}$

While about half of our cases died from causes reasonably associated with fibrotic lung disease (including respiratory infection, cor pulmonale, respiratory failure, and pulmonary embolism), it is of interest that in this middle-aged and elderly population non-respiratory deaths accounted for nearly half of the total. In particular, deaths from cardiovascular disease showed a fourfold increase, a feature previously noted by Stack et al. ${ }^{2}$ The explanation may lie in the fact that death from many causes tends to increase in ill and debilitated elderly patients.

Of particular interest is the increased incidence of death from lung cancer. This was observed in $12 \%$ of the present series and was observed previously by Stack $e t a l^{2}$ in four of $68(7 \%)$ and by Murao et $a l^{5}$ in $8 \%$ of 113 patients. More detailed consideration of lung cancer in CFA will be discussed elsewhere. ${ }^{11}$

This overview of the clinical features of CFA and their influence on overall survival in a relatively large population may provide useful background information for comparative purroses in future studies on pathogenesis and treatment. In the present study we have also identified a number of factors influencing survival which must be controlled in any formal therapeutic trial.

We thank all the physicians at the Brompton Hospital who allowed us to include their patients in this study and the many physicans throughout the United Kingdom who kindly provided followup data. We are grateful to Dr KWF Hinson for analysing the biopsy and necropsy material and to Dr David Brown for help with the computer analyses. We are also grateful to $\mathrm{Dr}$ Michael Lebowitz for the analysis of data for table 7 and for reading and criticising the text. During the course of the study Dr Burrows was a Macy Faculty Scholar. 


\section{References}

1 Livingstone JL, Lewis JG, Reid L, Jefferson KE. Diffuse interstitial pulmonary fibrosis. A clinical radiological and pathological study on 45 patients. Q J Med 1964; 33:71-103.

2 Stack BHR, Choo-Kang YFJ, Heard BE. The prognosis of cryptogenic fibrosing alveolitis. Thorax 1972; 27:535-42.

3 Crystal RG, Fulmer JD, Roberts WC, Moss ML, Line BR, Reynolds HY. Idiopathic pulmonary fibrosis: clinical, histologic, radiographic, physiologic, scintigraphic, cytologic and biochemical aspects. Ann Int Med 1976; 85:769-88.

4 Carrington CB, Gaensler EA, Coutu RE, Fitzgerald MX, Gupta RG. Natural history and treated course of usual and desquamative interstitial pneumonia. $N$ Eng J Med 1978; 298: 801-11.

5 Murao M. Idiopathic pulmonary fibrosis. Report of the nationwide project research in Japan. XIII World Congress on Diseases of the Chest. Chest 1980; in press.

6 Turner-Warwick M, Haslam P. Antibodies in some chronic fibrosing lung diseases. 1. Non organ-specific auto antibodies. Clin Allergy 1971; 1:83-95.

7 Cotes JE. Lung function assessment and application in medicine. Third edition. Oxford: Blackwell, 1975.
8 UICC Committee. Cincinnati classification of thes radiographic appearances of pneumoconiosis: $a 0$ co-operative study by the UICC committee. Chest 1970; 58:57-67.

9 Peto R, Pike MC, Armitage $P$ et al. Design and analysis of randomized clinical trials requiring prolonged observation of each patient. $\mathrm{Br}$ tes Cancer 1977; 35:1-39.

10 Turner-Warwick M, Burrows B, Johnson A: Cryptogenic fibrosing alveolitis: response to cor $\vec{\omega}$ ticosteroid treatment and its effect on survival. Thorax 1980; in press.

11 Turner-Warwick M, Lebowitz M, Burrows $B$ Johnson A. Cryptogenic fibrosing alveolitis and lung cancer. Thorax 1980; in press.

12 Dreisin RB, Schwartz MI, Theofilopoulos AN $\vec{V}$ Stanford RE. Circulating immune complexes ino the idiopathic interstitial pneumonias. $N$ Engl $\mathcal{P}$ Med 1978; 298:353-7.

13 Wright PH, Heard BE, Steel SJ, Turner Warwick M. Trephine biopsy histology in the management of cryptogenic fibrosing alveolitis. In preparation.

14 Eisenburg H, Barnett E, Simmons H. Diffuse pul-@ monary interstitial disease: an immune complex disease. Clin Res 1977; 25:132A.

15 Turner-Warwick M, Haslam P, Weeks J. Antibodies in some chronic fibrosing lung diseases. II. Immunofluorescent studies. Clin Allergy $1971 ;$ 1:209-19. 